\title{
Functionality of public spaces in historical urban layouts as based on Zamość and Lwów. Comparative analysis of selected components of city spaces in the context of the development and propagation/ promotion of Zamość and Lwów
}

\author{
Katarzyna Kielin \\ k.kielin@pollub.pl
}

Yaryna Protsiv

yarysia33@gmail.com

Department of Civil Engineering and Architecture, Lublin University of Technology

\section{Introduction}

Development of cities sprouts from human potential. By limiting, restricting access to public spaces for people of every age, perceptive or motoric ability, the prospects of fruitful, inspirational encounter, forging friendship or fall in love become downrightly limited. Sameness is stagnant. Diversity brings to a city constant movement. . Polish Language Dictionary defines "functionality" ("funkcjonalność") as "useful, helpful, ergonomic, efficient" which in relation to public space design refers to sufficient space for approach and use, convenient dimensions, operational simplicity and precise purpose of the place. Cities such as Zamość, with clearly defined, planned urban structure, pose a great challenge to designers in terms of balancing innovative, practicable architectural facilities that would not interfere with historical substance of a world heritage monument. In other words, designing in a historical centre is like walking on thin ice with the risk of distorting the integrity and original outlook of the centre.

Zamość is a unique example of a Renaissance town designed at the end of the $16^{\text {th }}$ century which retained its original urban/ communication layout, fortification system and a great amount of important buildings that combine both Italian and middle - European building practices.

\section{Historical overview}

\section{The Lviv Square}

The square was formed right after the foundation of the city during Lew Halicki's ruling in the $13^{\text {th }}$ century. At the beginning, the building substance acquired a gothic form. The city underwent great fire in 1381 . In 1452 , the square together with the main roads were paved. The next great fire happened in 1527 after which the square was rebuilt in a Renaissance style. In 1895, tramway route was introduced to the square. In 2006 , the Square and fountains underwent conservation. 


\section{STOPIEŃ PRZEKSZTAŁCENIA TKANKI MIEJSKIEJ LWOWA NA PRZYKKADZIE URBANISTYCZNYM}


\section{Lviv, The Promenade (Prospekt Swobody)}

The place of today's promenadę used to be covered with fortifications. After the annexation of Galicia to the Austrian Empire in 1722, the $3^{\text {rd }}$ line of the Lviv fortifications - Wały Hetmańskie were put down and replaced with a new form - a promenade. In 1893, a tramway transportation system was introduced whereas, in 1900, the Lviv National Opera was finished and it started to play a dominant role the Promenade landscape. The promenade was rebuilt in 1941. 


\section{Zamość, The Stefanidesa Square}

The creation of Stefanidesa Square dates back to the first quarter of the XIX century which took place of the building block called Podwale Reformackie. First idea about the space was to arrange a walking garden-like area but, finally, in 1850, it was accommodated for military store (storage). Once the store had been demolished, a new market space was introduced until 1960. Between 1963-1975, it was transformed into the main bus station area. Its current name has functioned since 1988, whereas before that time, the square was known as Hetmana Jana Zamoyskiego. The surface of the square is covered with clinker elements which was a popular paving system present in the Lubelskie region after the $1^{\text {st }}$ World War. The first government clinker factory was built in Zamość in 1884, by an engineer Florian Siennicki. From 1885, the factory went under governance of eng. Józef Zborowski. By 1915, all the streets located in the centre of Zamość were covered with clinker (zendrówka) 4.

The Stefanidesa Square (Plac Stefanidesa) has functioned as a primarily communication space dating back to the 50 . And 60 . When apart from bus station there was a taxi stand next to the Lubelska Gate (5-6 taxi vehicles had their main stop there). Until the $50^{\prime}$ of the XX c., the space functioned as a trade venue.

After the dissolution of the Zamość Fortress, a substantial space for the market purposes was delimited between Saint Catherine's Church, the New Lublin Gate and the first line of the Old Town tenement houses, a kehilla house, a slaughterhouse. Apart from the New Town Market Square, it was a second such a big vending space where household goods, pieces of furniture were sold. ${ }^{1}$ S. Popek, in ,"Dwunaste skrzypce", 2011 wrote: "The Thursday hustle and bustle/ atmosphere of a market space situated on the outskirts of the Old Town was a very picturesque one. Starting from the space of the Zoological Garden towards the moat bordering the Planty area, the New Lublin Gate, the Retrenchment a vast plain was filled with differently positioned single-horse, multiple-horse-drawn wagons cladded with straw, hay or seats covered with striped rug on which nicely looking, wooden-like cabinets, tables, children cribs, wicker baskets, sieves. Different horse coats only added to that scenic charm."

\section{Zamość, The Amphitheatre}

The space which now resembles the original ravelin, used to serve as a city amphitheatre. The object was designed by Maciej Pawlicki and was inspired by the ancient Epidauros. ${ }^{2}$ It was built between 1971-75 and was planned for 3600 seats. The stage had $24 \mathrm{~m}$ in diameter, later it was covered with a roof. Under the main layout of the audience section, in 1977, the "Wawel" sweets shop was introduced. Between 1977-83, a restaurant/ cafeteria "Widokowa" was introduced. The place served as a perfect space for holding theatrical performances from The Zamość Theatrical Summer. In the $70^{\prime}$ and $80^{\prime}$ the area brimmed with recreational amenities. The $90^{\prime}$ welcome the space with a cult ,"Club 10" demolished at the beginning of a second decade of the XXI c. Once it underwent restoration in 2012, partially financed from the European Union Funds, in spite of a new layout with the audience turned towards the urban centre, the space seems, rarely used, if not abandoned. ${ }^{3}$

\section{Examples of good practices in relation to universal design principles}

In spite of some difficulty connected with introducing design solutions that would meet the standards of a historical cityscape, there are some successful examples. The following outdoor ramp in Ravenna, Italy fills into the first universal design rule - Equitable Use as it is situated in between each staircase. The paving finishing corresponds to the surrounding surface while handrail does not stand out from the context. The materials chosen merge with the other elements of a city landscape. 


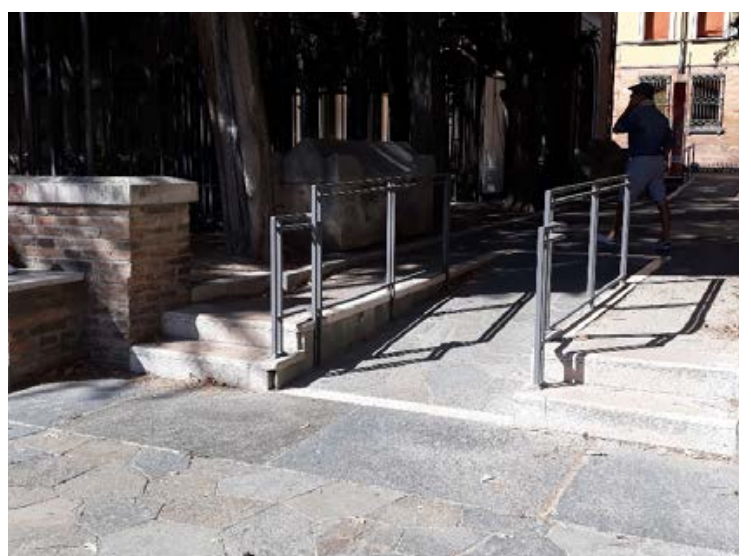

Fig. 1. A ramp, Ravenna; Photo: Katarzyna Kielin

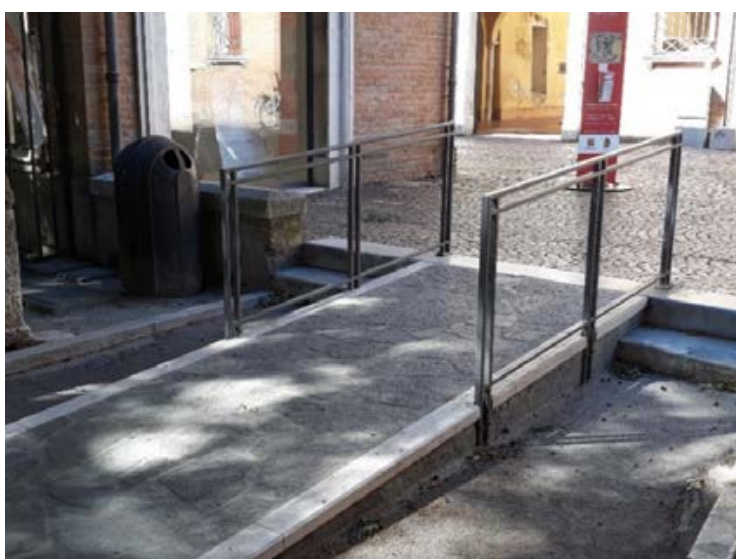

Fig. 2. Open door ramp, Ravenna; Photo: Katarzyna Kielin

Another good examples are a platform installed inside the Basilica of San Vitale in Ravenna and a tactile tyflographic model of the Basilica situated at the entrance on its terrain.

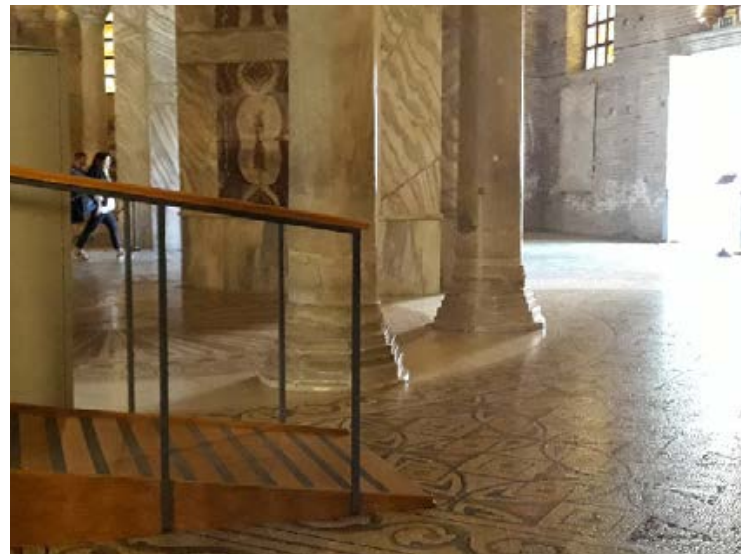

Fig. 3. A ramp placed inside the Basilica of San Vitale, Ravenna. Photo: Katarzyna Kielin

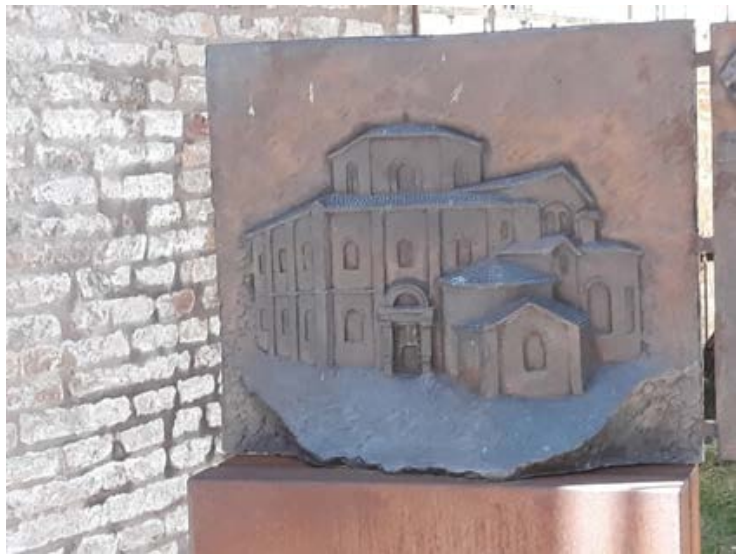

Fig. 4. A tactile model of the Basilica of San Vitale. Photo: Katarzyna Kielin

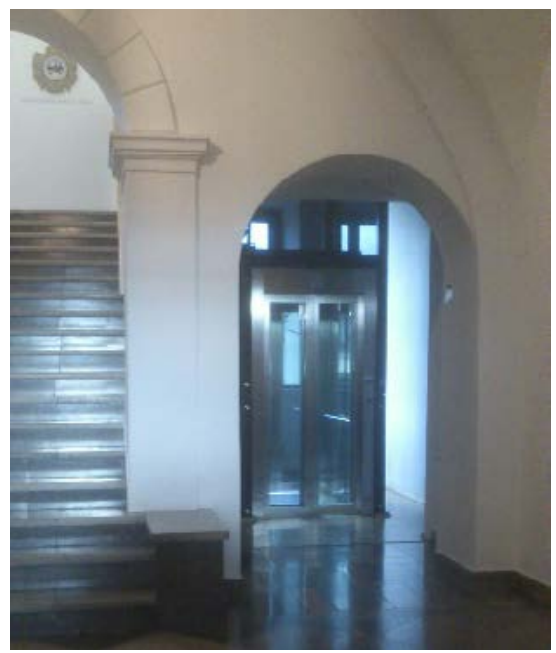

Fig. 5. The lift installed in the Zamość Town Hall, Zamość. Photo: Katarzyna Kielin

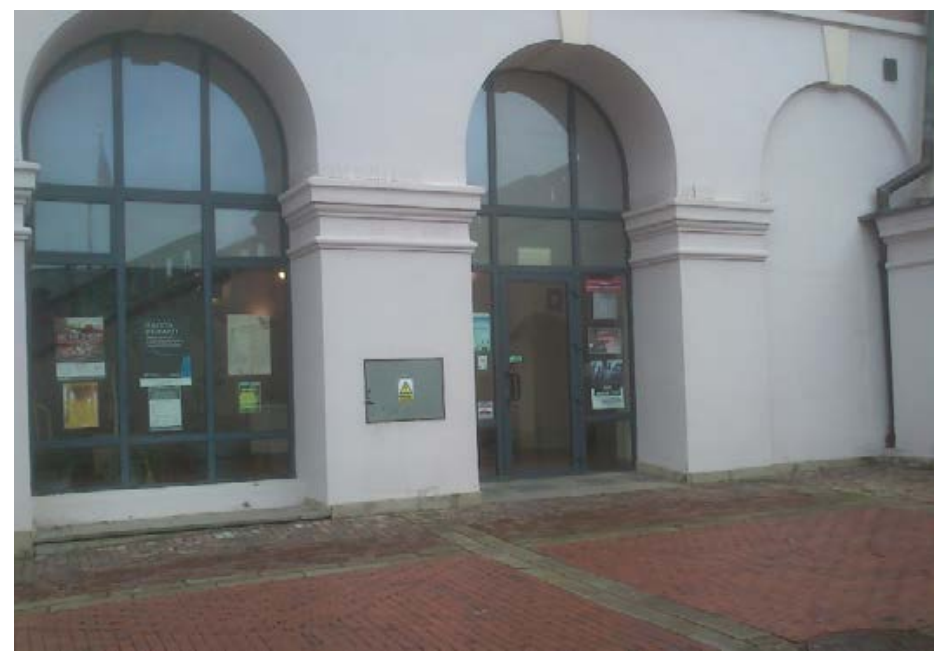

Fig. 6. The entrance to the Town Hall Customers' Office. Access provided by means of a small ramp, Zamość. Photo: Katarzyna Kielin 
It is worth-mentioning that there are some valuable examples present in Zamość itself. Namely, for over two years there had been some discussion concerning the fact of whether to install a lift inside the Zamość Town Hall. After the heated debate (relating to the Zamość Conservation officials) among the groups interested in the topic (communities of people with disabilities and their families together with the city officials from the Voivodship Historic Monuments Preservation Office. After thoughtful igniting the discussion from the people with disabilities themselves the project was successfully brought to an end and the lift connects the groundfloor with the second floor where there is the Consulatus Room - a place where the city council meetings are organized.

The majority of the chemist's venues located along the streets adjacent to the Promenade with sound system installed at the neighbouring crossings.

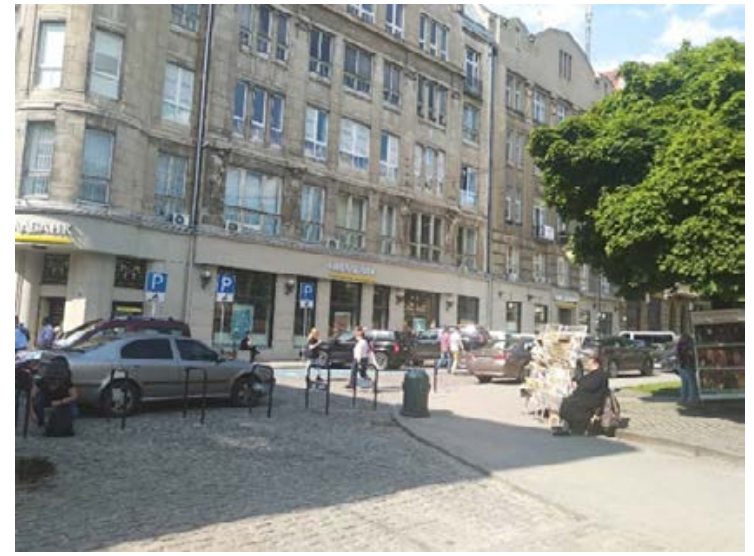

Fig. 7. Accessible parking place, Galicka St., Lviv. Photo: Yaryna Protsiv

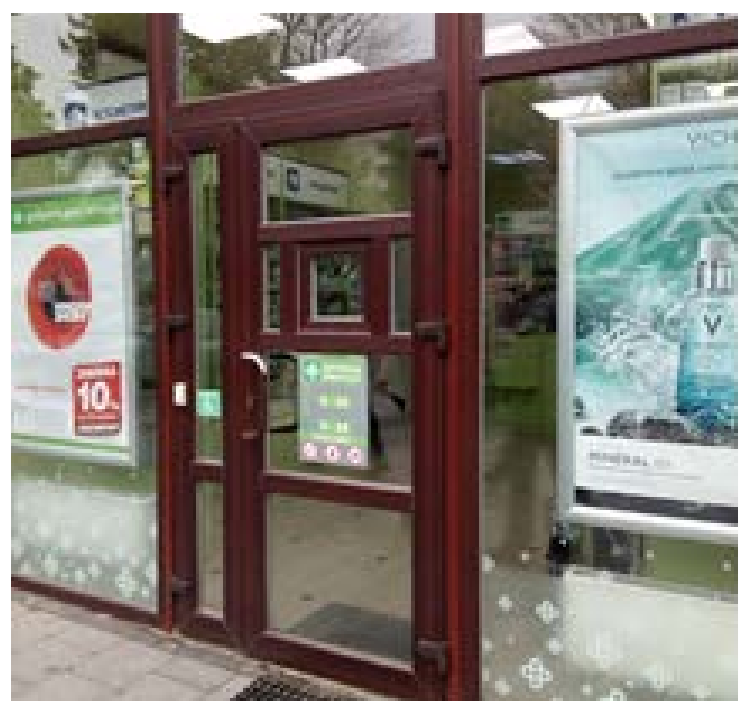

Fig. 9. Elevated pavement towards the line of the entrance, Lviv. Photo: Yaryna Protsiv

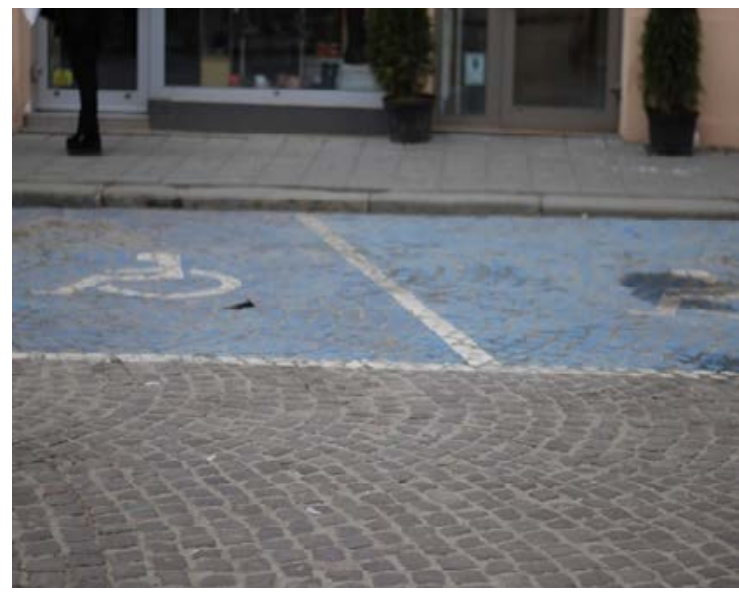

Fig. 8. Accessible parking places, Lviv; Photo: Yaryna Protsiv

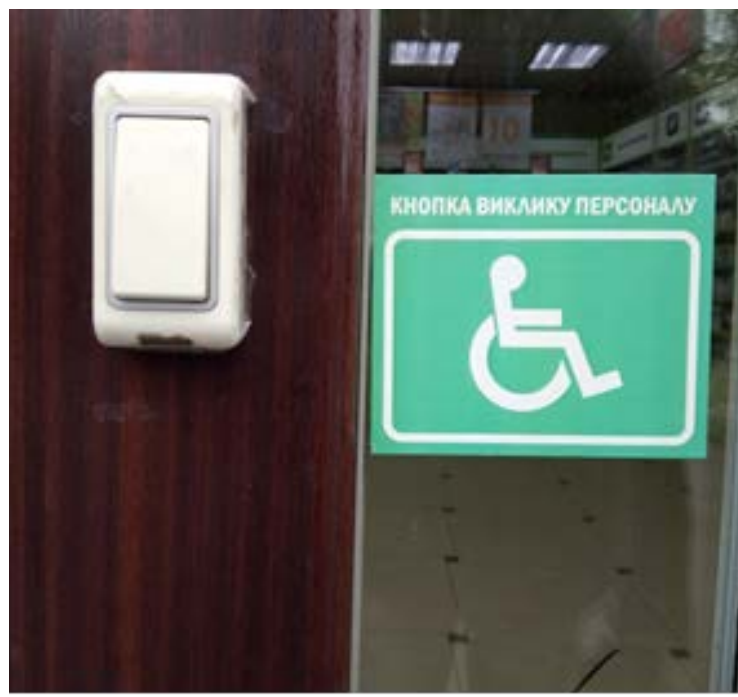

Fig. 10. Visual and sound information, Lviv. Photo: Yaryna Protsiv

Propagating universal design approach among young generations of architects happens by means of creative competitions. One of them is a contest organized by the Swiss producer of lifts - Schindler and called: all-European urban and architectural Schindler Award Competition "Access for All". It targets young, innovative and creative students of architecture having at the same time a very educational and humanistic dimension. The competition aims at restoring and enlivening forgotten city spaces in the name of "inclusive urbanism" and 
tries to add new value to the revitalized spaces. The organizers want to raise awareness among soon-to-be professionals in the field that universal design is more than just implementing ramps and lifts, but it is also proposing solutions to integrate different people, thinking about accessibility at a conceptual, preliminary stage of a design instead of final parts of a project. The contest is about shaping human-oriented, conscious approach to designing.

\section{Comparative analysis of selected Zamość and Lviv spaces}

One of the major problems concerning functionality of the analysed space is the lack of order in terms of zoning. There is no clear - cut channeling of movement; taxi car, autobus, pedestrian and private car traffic neither on the surface nor in the city signing system. Regardless of the fact that, originally, the space in question was not a distinguished, part in the Morando urban layout, currently it performs a function of a gate-like area. The Stefanidesa Square is the first space that is seen from the Lublin direction. Its predominant attribution is communication with a dominant role for car automobile traffic. The pedestrian movement is only restricted to the walkway situated on the northern part of Łukasińskiego St. and the distance from the roundabout around the terrain of St Catherine's Church. Furthermore, the space has no physical or psychological closure even though there are some elements, such as the Lublin Gate or a restored fragment of a fortress wall. Technical condition of paving elements is unsatisfactory. The surface is partially clinker and asphalt with some amount of cracks and lowered fragments where the rainwater accumulates. The crossing situated in front of the Lubelska Gate has got a partially lowered kerb line on one side of the street, on the other side, there is not any kerb edge along the street-walkway line. The space is not surrounded by clear urban walls therefore, the perception of the space as a regular square might be less probable and it serves as a transitory, solely passing-by space. The points which attract people's attention are shops, services, fast food restaurants and bars located along southern part of the area. Not only are they aesthetically questionable but also inaccessible with two, three steps without any architectural aids such as ramps, assisting devices or even surface. The advertisements placed on each southern building display some incongruency in terms of size, layout of individual elements or the level on which they are positioned. The rank of the place will deteriorate if no focal point such as, for example, main information point supplemented with some cultural and gastronomical function is not introduced. The space is highly indefinite in relation to.

It is important to mention that the space might act as the entrance zone if, metaphorically speaking, the Great Market Square is regarded as a salon space in a city centre "apartment". One can observe a gradation of spaces. Today's Stefanidesa Square needs careful rethinking.

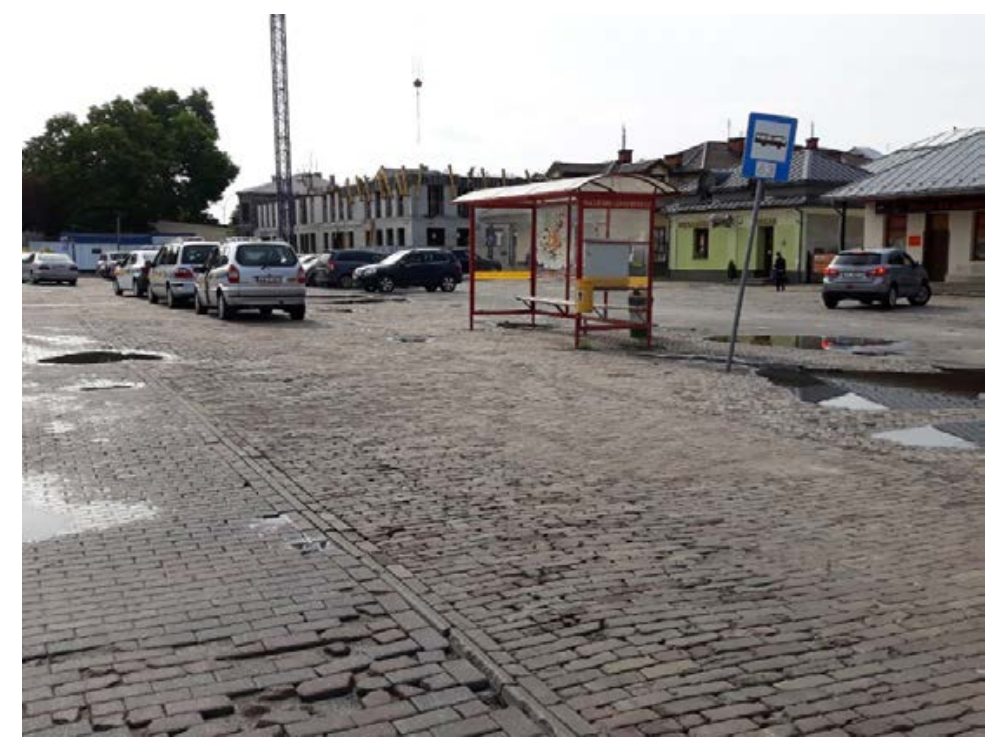

Fig. 11. The bus stop area without clear road - pavement boundary, Zamość The Stefanidesa Square. Photo: Katarzyna Kielin 


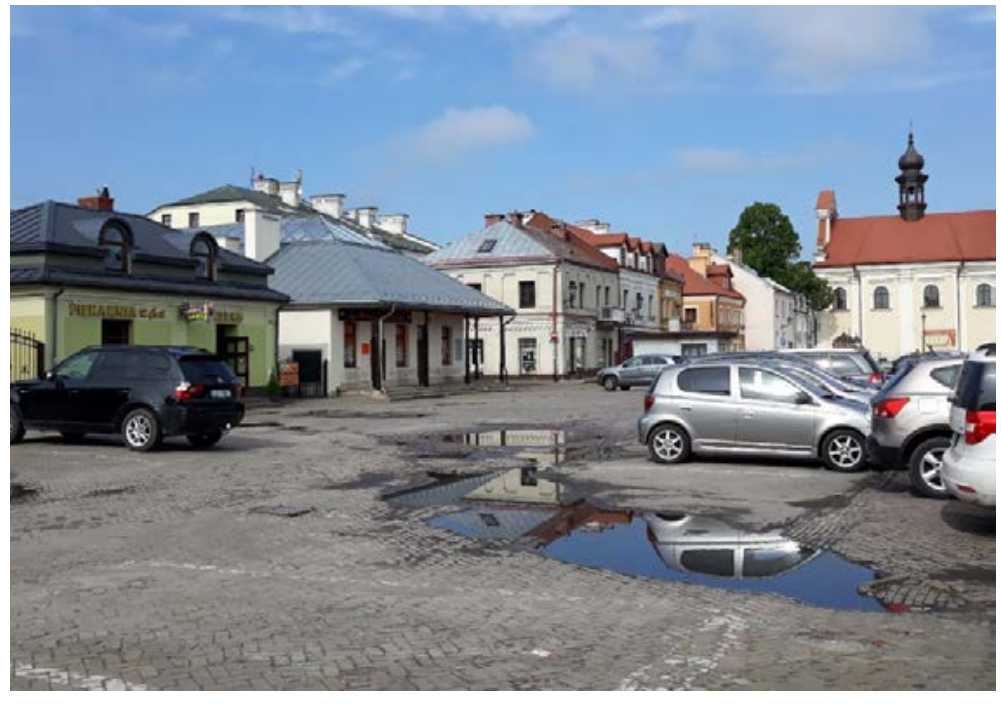

Fig. 12. Uneven clinker surface in the parking area, 2-3-step difference in the areas of the entrances to the groundfloor shops and services, Zamość, The Stefanidesa Square. Photo: Katarzyna Kielin

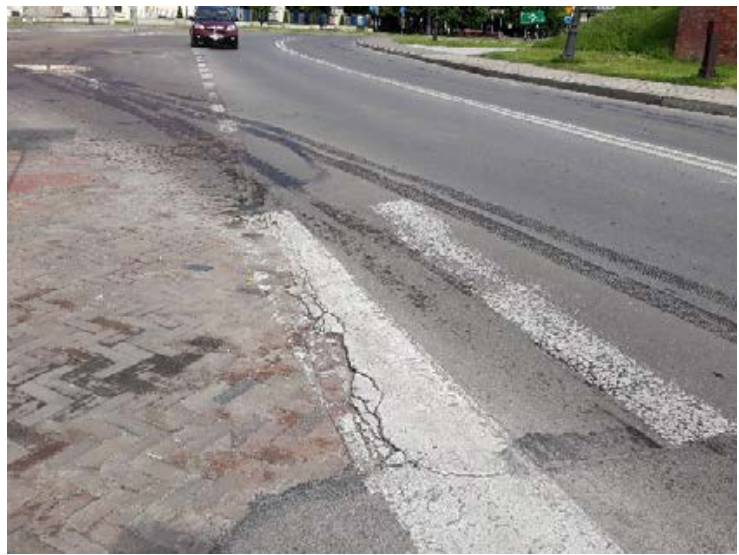

Fig. 13. The lack of pavement at the pedestrian crossing, The Stefanidesa Square, Zamość. Photo: K. Kielin

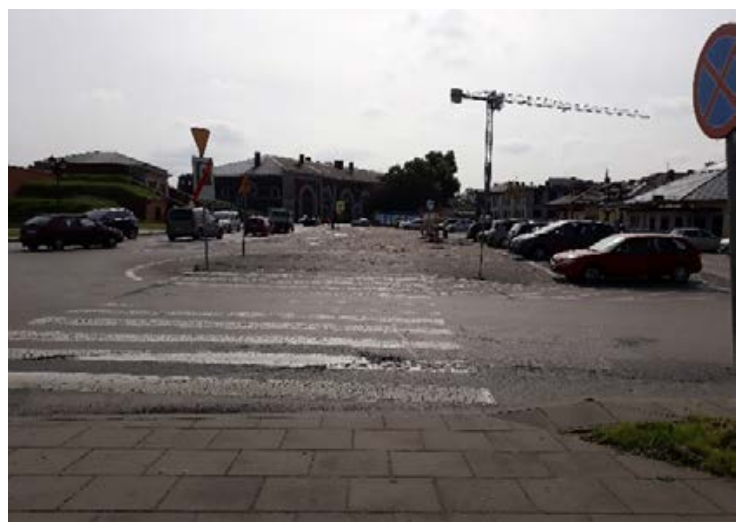

Fig. 15. A pedestrian crossing linking a regular pavement with the parking zone, The Stefanidesa Square, Zamość. Photo: K. Kielin

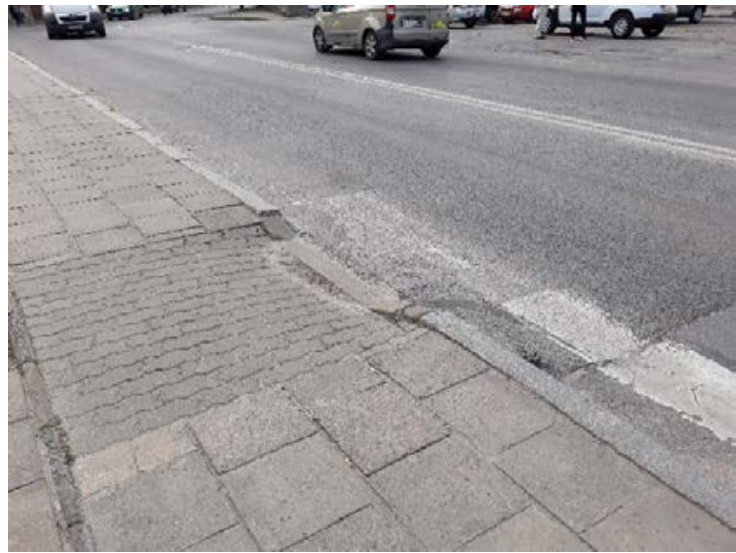

Fig. 14. Limited access to the zone of the pedestrian crossing The Stefanidesa Square, Zamość. Photo: K. Kielin

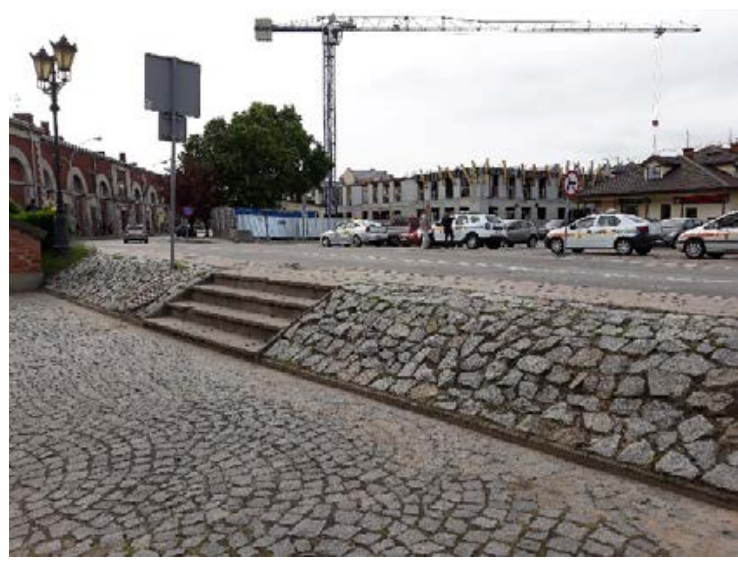

Fig. 16. Lowered frontal surface adjacent to the New Lublin Gate, The Stefanidesa Square, Zamość. Photo: K. Kielin 


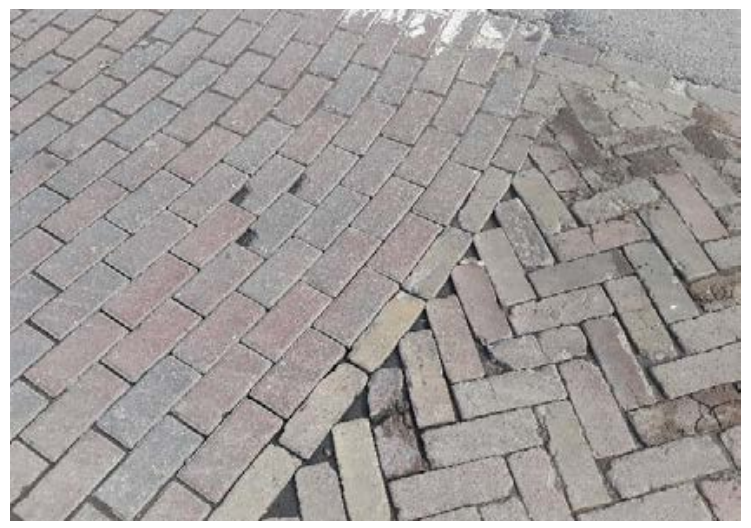

Fig. 17. Clinker paving is a traditional type of surface (one particular type: zendrówka), The Stefanidesa Square, Zamość. Photo: K. Kielin

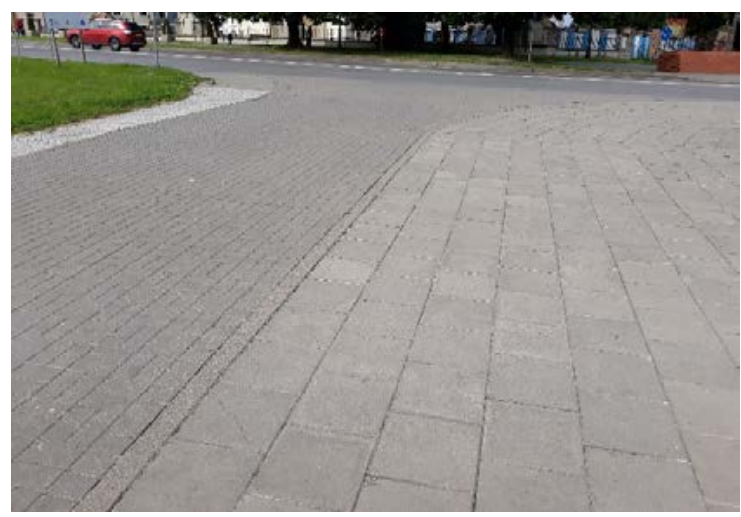

Fig. 19. Positive example of a comfortable walking surface, easy wheelchair access, The Stefanidesa Square and The Amphitheatre, Zamość. Photo: K. Kielin

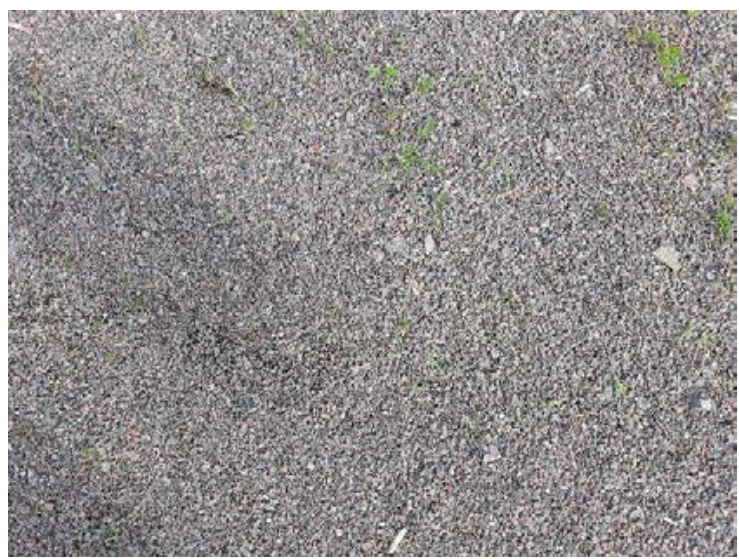

Fig. 21. Walkway surface around the audience zone at The Amphitheatre, The Amphitheatre, Zamość. Photo: K. Kielin

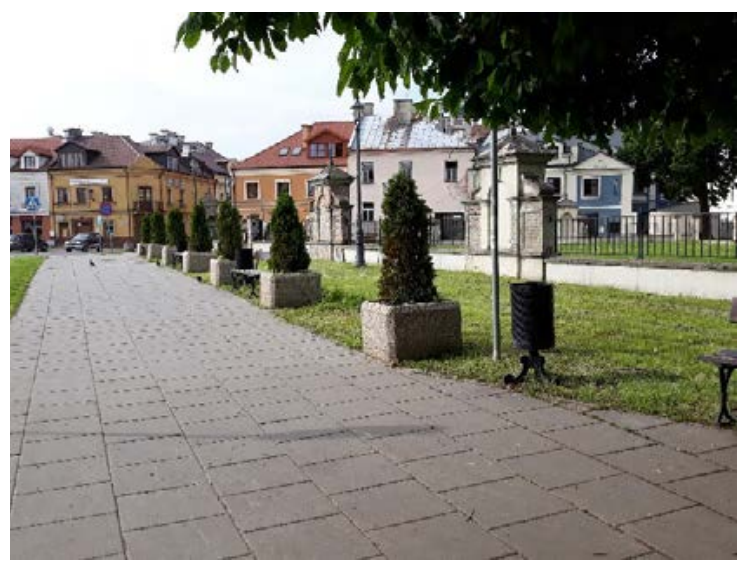

Fig. 18. Concrete squared tiles fall successfully under the UD principle of "Low Physical Effort"

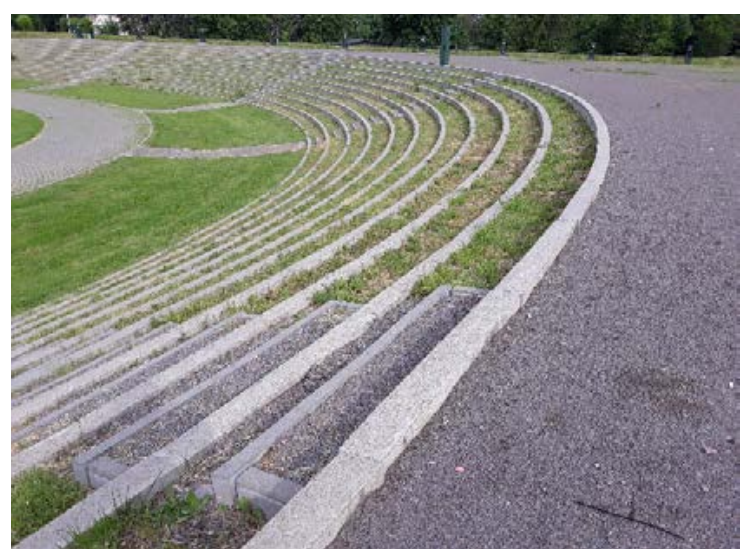

Fig. 20. The amphitheatre surface and audience finishing, The Amphitheatre, Zamość. Photo: K. Kielin

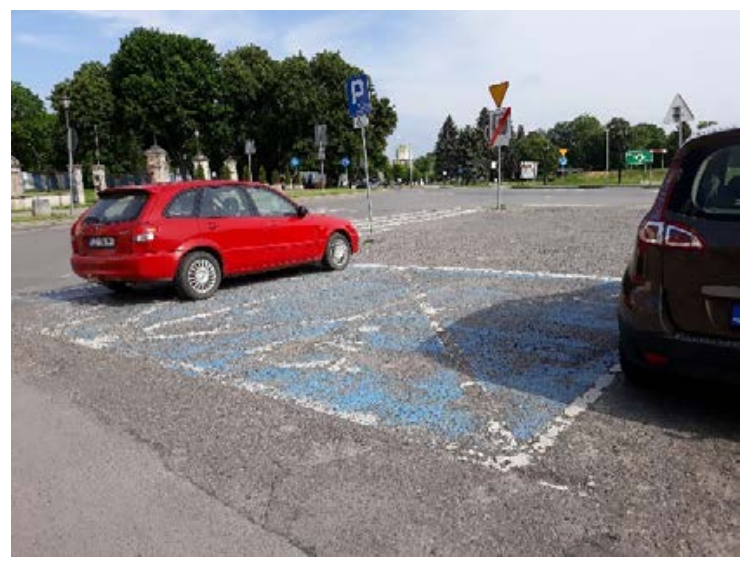

Fig. 22. Accessible parking places, The Stefanidesa Square and The Amphitheatre, Zamość. Photo: K. Kielin 
The map, The Promenade

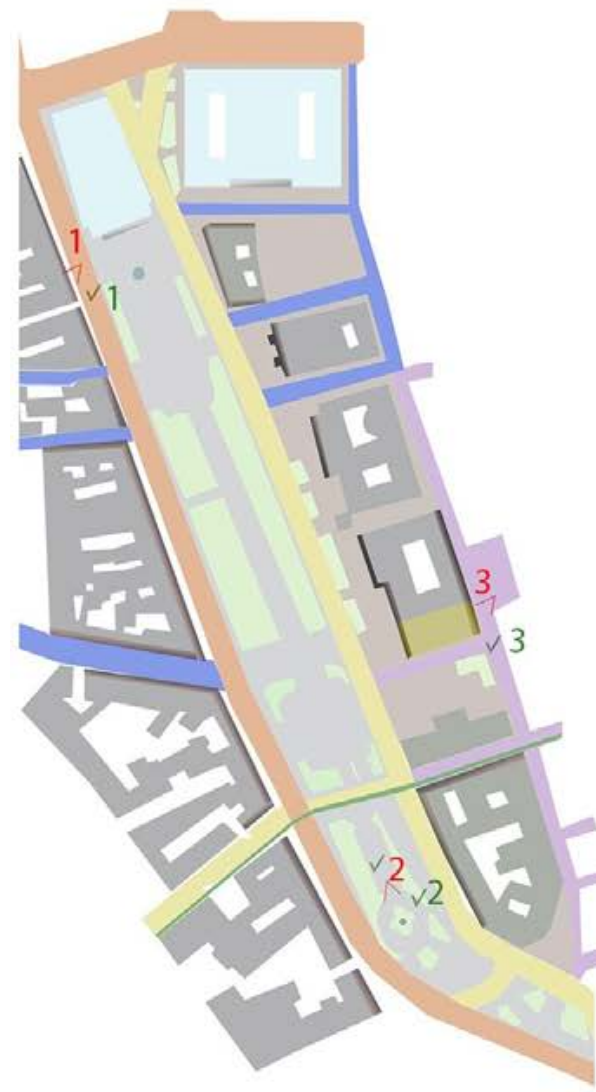

LEGENDA:

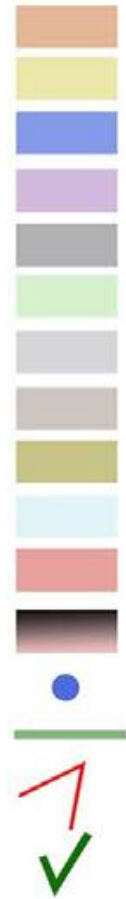

- droga główna

- droga zbiorcza

- droga lokalna

- droga dojazdowa

-zabudowa

- zieleń

- nawieszchnia dostosowana

- bruk

- budowla sakralna

- budowla teatru

- budowla administracyjna

-strefa wejsciowa do usług gastronomicznych handlowych $\mathrm{i}$ sakralnych

- pomnik,fontana

- linia tramwajowa

- kierunek robienia zdjęcia

-fragment nawierzchni
The entrance zones

Paving systems

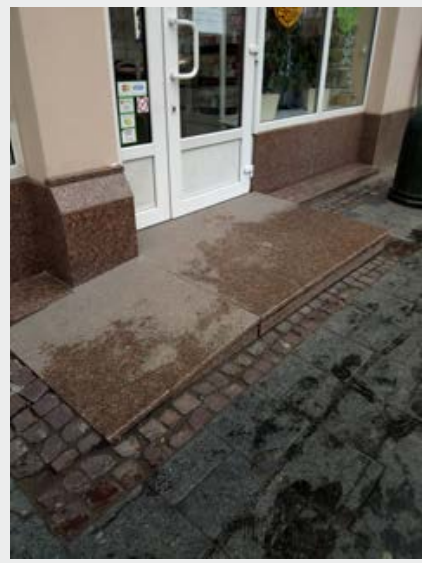

1

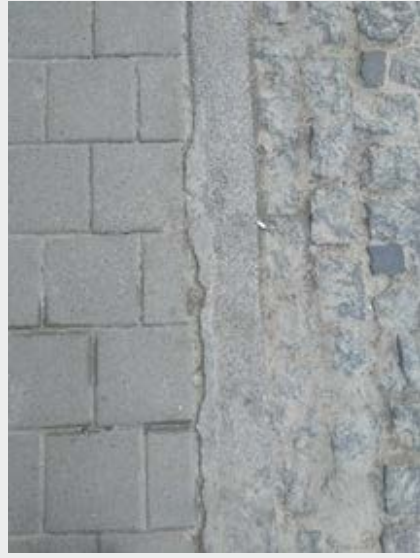

$1 \mathrm{~V}$

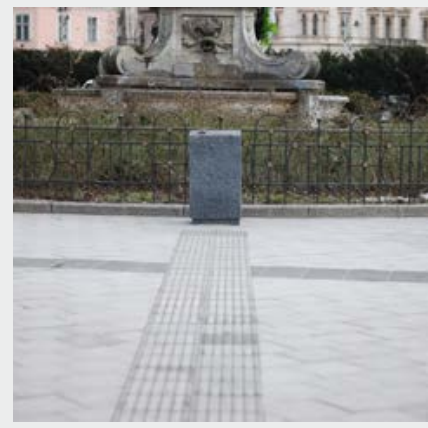

2

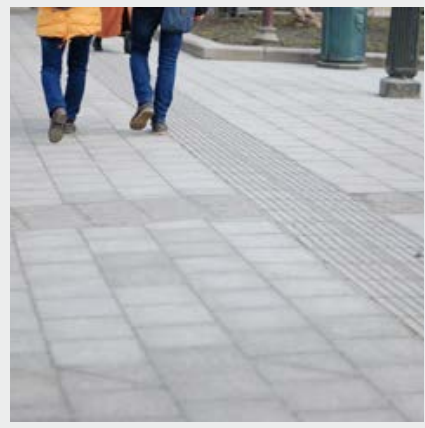

$2 \mathrm{~V}$

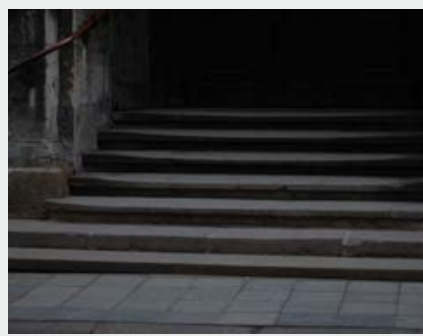

3

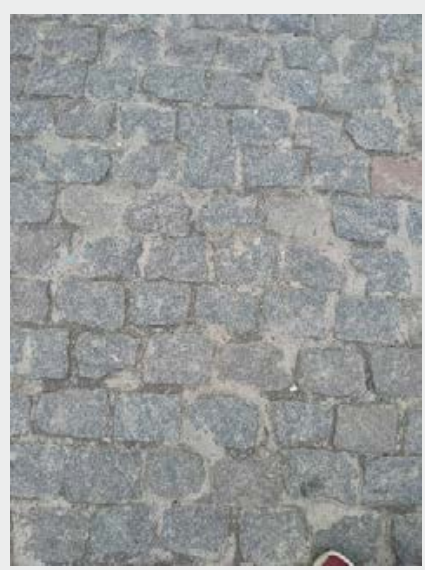

$3 \mathrm{~V}$ 


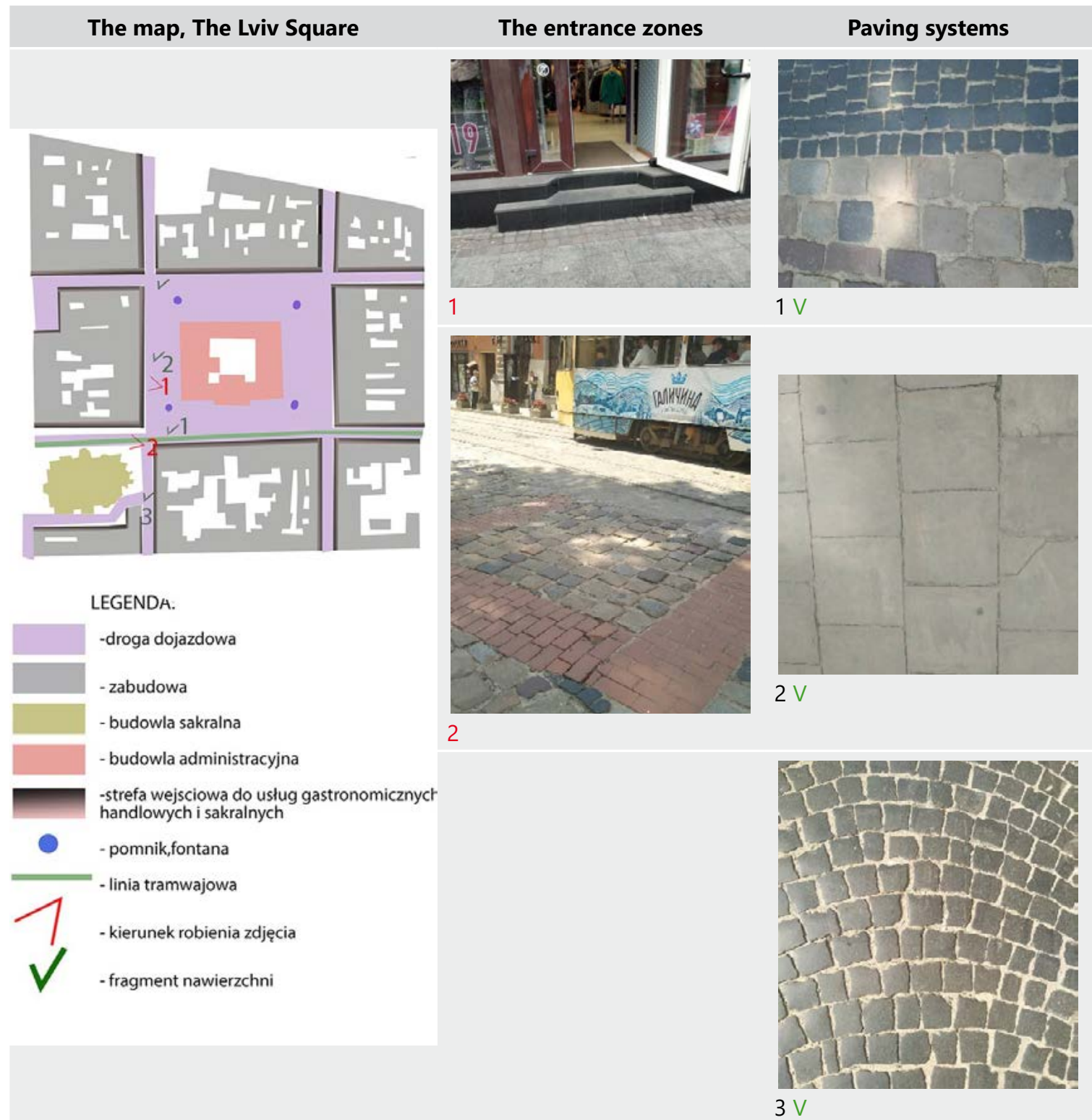

\section{Conclusion}

In both cities there is a problem of inadequate paving systems which are characterized by great amount of variation, unsuitable for the use by people with motoric impairments or temporary difficulties with walking. The situation might be bettered, especially taking into account low degree of compositional impact on a historical surrounding. Among the most common paving elements are: granite, clinker, concrete squared tiles, asphalt. Altering the walkways should be the most fundamental step towards increasing safety and accessibility. Accessibility of a city space (physical aspect of space) refers directly to a city's organizational capacities. As Jacek Szołtysek claims: "The reason for any disability does not come from an individual inherent limitations but from inadequate/ insufficient public awareness and inaction which leads to/ causes physical, social, legal or economic barriers." In other words, in order to create a well- designed space, it is reasonable to discuss its "eficacy" and "suitability"/ fitness. 
Zamość remains a town of some remarkable architectural and urban qualities as well as an undisputable cultural heritage status. It was acknowledged as The Monument of History for being a "Historical fortified urban layout from the XIX c." In the context of conservation practices, the problem of full accessibility of public space, especially a communicational grid, is in as much difficult as indispensable. All the design actions focused on the promotion of Historical Monuments should incorporate universal design principles advocating better understanding of people with dissabilities, especially in relations to current revitalisation processes being implemented in major historical objects such as the Cathedral and The Franciscan Church. Both Zamość and Lwów are on the UNESCO World Heritage List.

The paper discusses the degree of selected public space accessibility of Zamość and Lviv in relations to the needs of people with motoric impairments. Among the criteria discussed there are:

- A technical quality of different types of Surface

- Entrance zones to service and vending points, small restaurants

Taking into consideration universal design aspects during the discussion about touristic and promotion opportunities of the Monument of History as well as formulating standards of preservation and management of the most valuable historical sites in Poland, should be of top priority. The more people have a chance of experiencing public spaces of historical towns, the better. The procedure of honoring a place with the title of the Monument of History has to include accessibility policy. 